\title{
Drought Assessment and Monitoring for Sustainable Production of Tef Crop and Land Management in Ethiopia Using Geoinformation Science
}

\author{
Ayalew, Balehager $1^{\text {st }}, \mathrm{Qu}$, John $2^{\text {nd }}$, Roper, William $3^{\text {rd }}$ \\ Environmental Science and Technology Center, \\ College of Science, \\ George Mason University \\ Department of GGS, MS6A2 Fairfax VA 22030 \\ bayalew@gmu.edu,jqu@gmu.edu, wroper@gmu.edu
}

\begin{abstract}
Agricultural sustainability has the highest priority in all countries, whether developed or developing. Geoinformation Science is gaining importance as useful precision farming Science in sustainable agricultural management and development. This research is intended to demonstrate the applicability of these tools in suitability zoning, information extraction and mapping for agricultural development of tef crops in Ethiopia. The crop species is indigenous and has its centers of both origin and diversity in Ethiopia. The solution for providing food security to all people of the world without affecting the agro ecological balance lies in the adoption of new research tools, particularly from aerospace Remote Sensing, and combining them with conventional as well as frontier technologies. Climate change variability and uncertain rainfall distribution in rainfalldependent farming areas, especially in arid and semi-arid ecosystems that have drought occurs every two years become one of the most important natural disasters and often results in serious economic, social, and environmental crises. This paper describes the process and purpose of creating these maps is in an attempt to locate regions of Ethiopia that are suited for current tef varieties or improved varieties that mature within a time frame. High spatial resolution has proven to be an important tool for crop discrimination, especially if considered that Geoeye-1 performed better than Rapideye. This result focuses on identifying drought beginning, end, spatial extent, and severity of the drought in a given region and is based on scientific reasoning. Once the analysis is conducted it is beneficial in developing drought policies, early warning monitoring systems, mitigation strategies, sustainable production management/development and preparedness plans.
\end{abstract}

Keywords-Sustainable Production Tef Crop, Food Security, Ethiopia, Geoinformation Science.

\section{INTRODUCTION}

Tef is the most important cereal grown in Ethiopia; annually tef accounts for about $28 \%$ of the total acreage and $19 \%$ of the gross grain production of the major cereals cultivated in the country (CSA 2008). [2] The rest of the world for the first time knew about tef in the 16th century through the Portuguese who came to give military aid to Emperor Susnyos of Ethiopia (Tadesse,1975). Many believe that tef has been domesticated for the last 3000 years in the Northern highlands of Ethiopia. However we cannot be sure for how long those people cultivated this ancient crop. [8] Show (1976) believes that tef is the first crop to be domesticated in Ethiopia before barley and wheat are domesticated; otherwise it would not have survived as a cultivated cereal. [7] Within the overall purpose of contributing to sustainable production of tef in Ethiopia, giving the previously mentioned needs for increased technology adoption for crop management and monitoring aiming higher yield rates, for the development of precision farming based methodologies promoting increase on tef per hectare crop production at the same time that environmental impacts are reduced.

\section{OBJECTIVE}

This research is strongly expected to advance the estimation of Tef crop production in Ethiopia through use of Geoinformation Science application for suitability of tef growing areas analysis and production development. The solution for providing food security to all people of the world without affecting the agro-ecological balance lies in the adoption of new research tools, particularly from space Remote Sensing, and combining them with conventional as well as frontier technologies like GIS. The broad objective of sustainable agriculture is to balance the inherent land resource with crop requirements, paying special attention to optimization of resource use towards achievement of sustained productivity over a long period.

\section{METHODOLOGY}

This document describes the process by which we built maps using GIS software.

[2] Central Statistical Authority (CSA), 2008: Statistical Abstract of Ethiopia 2008. Ethiopian agricultural research organization, Addis Ababa, Ethiopia.

[7] Show,T. 1976. Early crops in Africa: A review of the evidence. In. J.R. Harlan, J.M.J. Dewet and A.B.L Stemler (Eds.) Origins of African plant domestication, Moutn publishers, The Hague, Paris. PP.107-153.

[8] Tadesse Ebba. 1975. Tef (Eragrostifs tef) cultivates Rs. Morplogy and classification. Part II. Agricultural Experiment Station Bulletin, 66, Addis Ababa university, college of agriculture, Diredawa, Ethiopia 
The purpose of creating these maps is in an attempt to locate regions of Ethiopia that are suited for current tef varieties or improved varieties that mature within a time frame for the belg rain season, regional scale data on climate, topography, land use/land cover and soil data was organized in a GIS. Data was found using FEWS (Famine Early Warning System), USGS EROS, GTOPO30, and ETHIOGIS. More detailed data collection included a local scale (1:10.000) soil survey as well as high spatial resolution image based tef mapping.

A. Study Area Selection

Research area is located in sub-Saharan Africa, Ethiopia, Ada'a-debrezeit area in central highland of Oromia Regional State, East Shewa between Debrezeit and Mojo towns shown on Figure 1. The area was selected giving its concentration of tef fields and easy access. The UN Population Division/DESA stated that in 1999 Ethiopian population was 60.3 million with a $2.16 \%$ population growth and 2009 Ethiopia population is $82,825,000$ million and year 2050 expected to be $173,811,000$. The food crises of the 1970s and 1980s have drawn attention to the issue of environmental vulnerability and the need for its mitigation. Rapid population growth and limited arable land has rendered sustainable agriculture production and natural resource management a priority to feed a growing population and reduce poverty. Therefore, the active participation of farmers and rural communities in Ada'a-debrezeit area identifying problems, demonstrating and evaluating alternative technologies, and on-farm trials as adaptive research approaches to find possible solutions is needed to support and facilitate technology adoption. [9]

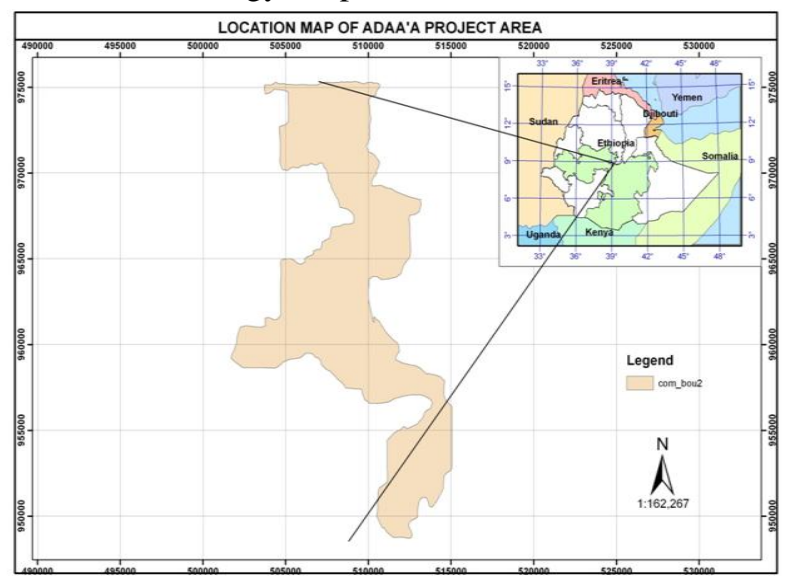

Figure 1. Location of the local scale soil survey and mapping study area.

B. Ethiopian Rainfall, Elevation Data

Rainfall data used to create the estimated average rainfall for the period of July 11 to October 10 is presented. Precipitation, topography and temperature data were downloaded from FEWS (Famine Early Warning System) for 5 years (20062010) was used to create an elevation range map suitable for tef growing. [6]

C. Ethipian Land Cover and Soil Characterstics Land Use/Land Cover and Soil type information/data collected from Ethiopian Institute of Agricultural Research, Debre Zeit Agricultural Research Center (EIAR-DZARC).

D. Ada'a-debrezeit area Soil Characterization
Soil forming factors, such as parent material, climate, topography, organisms (fauna and flora) and time were considered to be more or less independent from each other but can have simultaneous interactions. Therefore, the genesis of the soils identified in the survey area was the result of interactions between the soil forming factors. Waterworks Design and Supervision Enterprise and ETHIOGIS data was analyzed Ada'a-debrezeit area based on soil particle size distribution, bulk density, soil $\mathrm{pH}$ in $\mathrm{H} 2 \mathrm{O}$ and $1 \mathrm{M} \mathrm{KCl}, \mathrm{EC}$ $(\mathrm{ms} / \mathrm{cm})$ at a soil to water ratio, exchangeable $\mathrm{Na}, \mathrm{K}, \mathrm{Ca}, \mathrm{Mg}$ (meq/100gm of soil) following ammonium acetate leachate using Atomic Absorption Spectrophotometer (AAS), cation exchangeable capacity (CEC) following ammonium acetate method at $\mathrm{pH} 7$, organic carbon $(\%)$, total nitrogen, available phosphorus, p (Olson) mg p2O5 kg/soil, free $\mathrm{CaCO} 3$ (by acid neutralization method), and field capacity and permanent wilting points. Climate and time effects are most pronounced on stable surfaces. On such surfaces past climate instead of the present climates may account for the soil conditions. In some crest areas weathering and decomposition are pronounced giving rise to deep and slightly well developed soils (such as Luvisols). Topography plays an important role in soil genesis, primarily through modification due to the impact of climate. [5] Thus, on steeper slopes (close to mountains and hills) water runs of rapidly retarding soil development. Summary information of area coverage by each soil unit is indicated in Table 1.

\begin{tabular}{|l|l|l|l|l|}
\hline Major soil types & $\begin{array}{l}\text { Identified } \\
\text { soil unit }\end{array}$ & code & $\begin{array}{l}\text { Area } \\
\text { (ha) }\end{array}$ & $\begin{array}{l}\text { Area } \\
(\%)\end{array}$ \\
\hline $\begin{array}{l}\text { Cambisols } \\
\text { (CM) }\end{array}$ & $\begin{array}{l}\text { Vertic } \\
\text { cambisols }\end{array}$ & CMvr & $\mathbf{3 5 8 . 5}$ & 2.68 \\
\hline Luvisols (LV) & $\begin{array}{l}\text { Chromic } \\
\text { luvisols }\end{array}$ & LVcr & $\mathbf{1 2 7 1 . 0}$ & 9.50 \\
\hline Vertisols (VC) & $\begin{array}{l}\text { Chromic } \\
\text { vertisols } \\
\text { Pellic } \\
\text { vertisols }\end{array}$ & $\begin{array}{l}\text { VRcr } \\
\text { VRpe }\end{array}$ & $\begin{array}{l}4459.40 \\
\text { 6222.20 }\end{array}$ & $\begin{array}{l}79.7 \\
\mathbf{1 0 , 6 8 1 . 6 0}\end{array}$ \\
\hline $\begin{array}{l}\text { Hills, swampy } \\
\text { area }\end{array}$ & & H, S & $\mathbf{1 0 7 7 . 0}$ & 8.04 \\
\hline Total & & $13,388.10$ & 100 \\
\hline
\end{tabular}

Table 1. Major soils of the study area and their distribution

Basalt and other basic rocks are rich in ferromagnesian minerals which breakdown to clay minerals, resulting to clay textured soils. Major soils of the study area and their distribution showing in Figure 2 [9].

[9] "United States Geological Survey (USGS); (EROS) Earth Resources Observation and Science Center. http://eros.usgs.gov/\#/Find Data/Products and Data Available/gtopo30 info.

[6] FEWS (Famine Early Warning System) http://earlywarning.usgs.gov/fews/africa/web /datatheme.php

[5] ETHIOGIS. http://www.ethiogis.net/

[9] Waterworks Design and Supervision Enterprise http://www.wwdse.com.et/ 


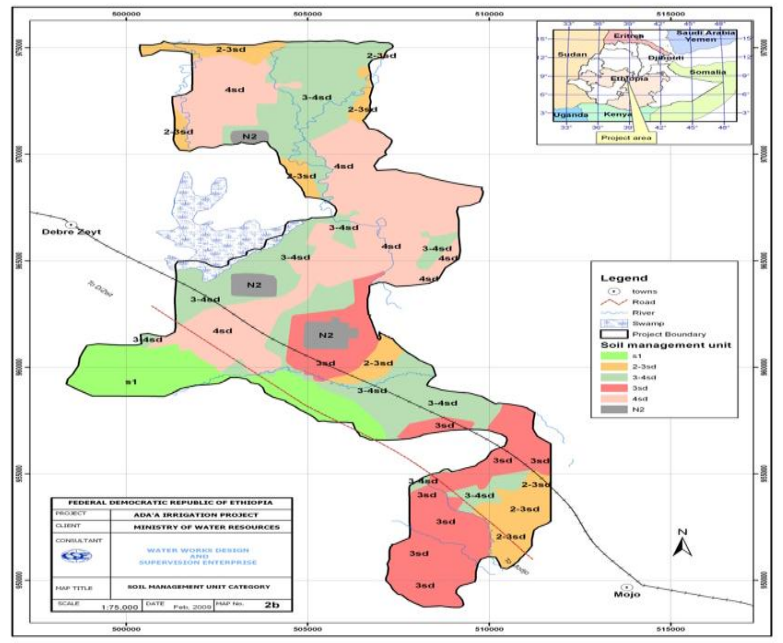

Figure 2: Adaa soil mapping unit

E. Sensors and Image Selection

Image availability for the period before tef sowing (growing) determined aquiring of Geoeye-1 data showing inf Figure 3. GeoEye Image acquisition date is 28 July 2011, 07:52 GMT (Greenwich Mean Time). Geoeye-1 image was provided with a file containing RPC information, used to orthorectify the image along with ground control points and the USGS GTOPO30 DEM. Resulting image is presented here in Geographic coordinates, datum WGS-84. [10]

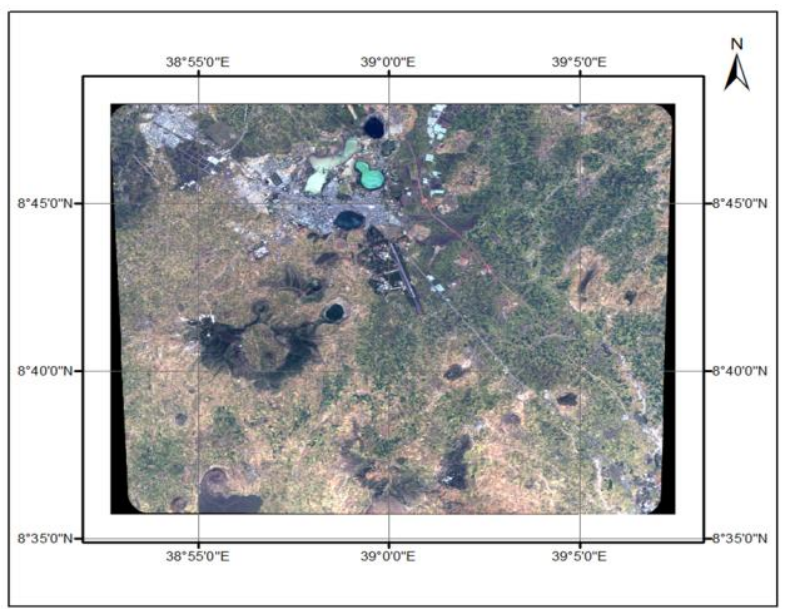

Figure 3. Geoeye-1 image in natural color composition (bands 3, 2 and 1 on R, $\mathrm{G}$ and $\mathrm{B}$ channels, repectively).

Tef field sampling data was collected over October 2011 growing season. During crop maturity period only Rapideye image was available showing in figure 4 . The image was acquired on 27 October 2011, 08:59:15.55 GMT. REIS (RapidEye Earth Imaging System). Rapideye Ortho image product is radiometric, sensor and geometrically corrected and aligned to a cartographic map projection. No mosaic was performed before image processing, to avoid alteration on pixels values.

Geoeye-1 and Rapideye images were classified using example based feature extraction workflow available on Envi 5.0 software. This software tool includes image segmentation and supervised classification routines. [4] Spectral classes used in image classification were combined into four main land cover/land use classes exposed soil, crops, trees and shrubs and and urban areas includes buildings, roads, and urban areas itself. Results from classification of the four Rapideye images were mosaicked. Change detection based tef identification was performed.

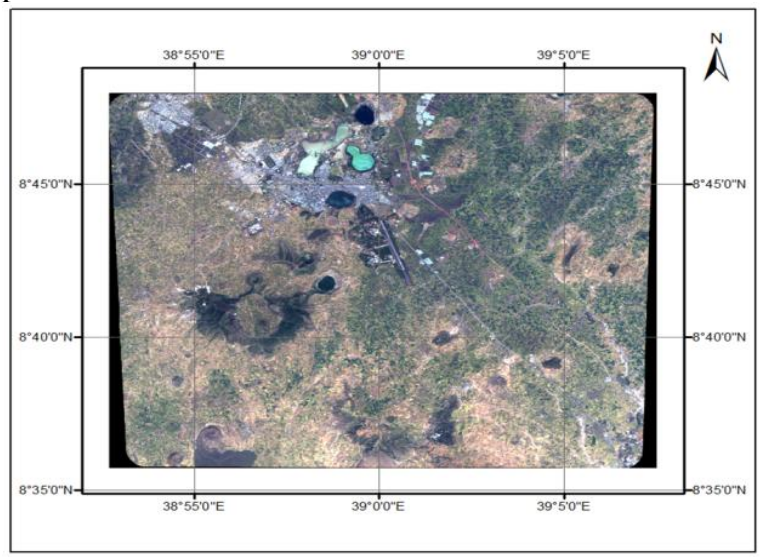

Figure 4. Rapideye image in natural color composition (bands 3, 2 and 1 on R, $\mathrm{G}$ and $\mathrm{B}$ channels, repectively).

Geoeye-1 classified image was used as the initial state, representing the period in which soil is bare previously to tef sowing and final state image were considered as tef, since no other crop is grown at the same time window as tef.

\section{IMAGERY ANALYSIS AT PLANTING AND NEAR HARVEST}

Object-based classification of Geoeye-1 image is presented in figure 5. When comparing this initial state change detection map and original image it can be noticed a good performance of segmentation based feature extraction algorithms used. Exposed soils dominate the landscape this time of year, before tef planting.

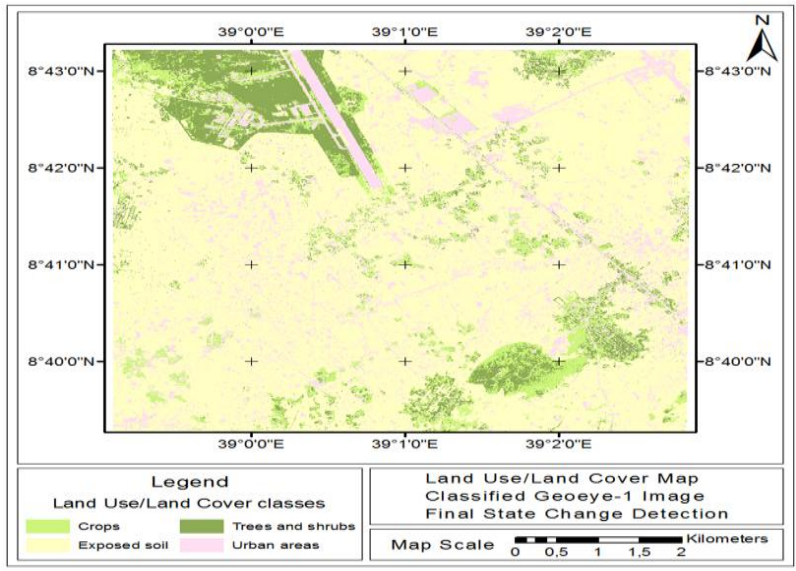

Figure 5. Geoeye-1 resulting object-based image classsification.

[10] "United States Geological Survey (USGS); (EROS) Earth Resources Observation and Science Center. http://eros.usgs.gov/\#/Find Data/Products and Data Available/gtopo30 info.

[4] Envi 5.0. Envi 5.0 User's Guide. Boulder, Colorado: Exelis 
Visual Information Solutions. 2011

$$
\begin{array}{cccc}
{[3]} & \text { Earth } & \text { Observation } & \text { Portal } \\
\text { https://directory.eoportal.org/web/eoportal/satellite-missions/g/geoeye-1 }
\end{array}
$$

Urban areas, crops and trees and shrubs classes are well defined as well. Rapideye image classification results visual analysis revealed a good classification for the main classes of interest, exposed soils and crops showing in fugure 6. Coarser resolution images presents higher levels of pixel impurity, especially on objects boundaries or when small objects occur inside bigger ones, such as trees in a field.

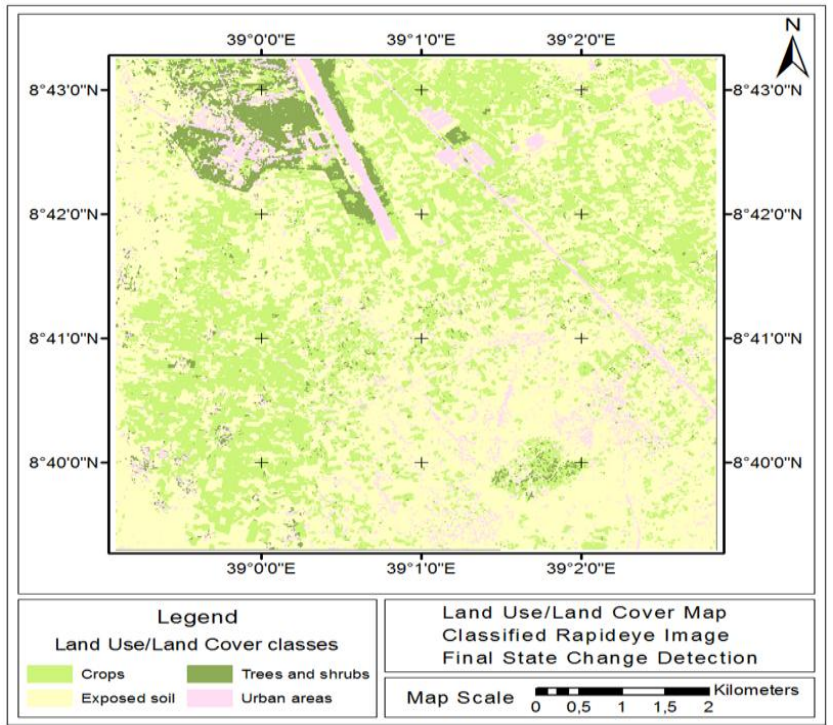

Figure 6. Rapideye resulting object-based image classsification.

In Geoeye-1 image trees are clearly defined, whereas some smaller trees almost disappear in Rapideye image, having its spectral response mixed to those of surrounding fields. Edge detection algorithm and full lambda schedule merging sets were adopted for image segmentation. Performance of SVM algorithm was superior to other algorithms and this is the one adopted in this study. These segmentation parameters were used for both images.

\section{CHANGE DETECTION ANALYSIS}

When comparing the final change detection maps to the original images, it can be noticed that this is the appropriate technique for tef mapping at local scales. Taking advantage of pronounced differences in multi-temporal images caused by characteristics of a rapidly growing crop such as tef is probably the best approach available for this kind of target detection.

On the other hand, a great amount of urban areas appear in the final change detection map showing in figure 7 . This error might be due to proximity of exposed soils and roads or urbanized areas and differences in image pixel sizes. Since Rapideye is a $5 \mathrm{~m}$ spatial resolution image, many of the pixels that should receive roads or exposed soil spectral responses are mixed or mistakenly captured while image is acquired. Use of same sensor or same spatial resolution images would avoid some of these errors. In square meters, it can be noticed that crops class presents the highest positive change from initial to final state, as expected. This class had a 296, 74 percent and 11.967.475, 00 square meters increase.

Although changes for exposed soils account for only $-21,30$ percent, absolute pixel values demonstrate this is the class that lost more pixels (-298.615) and crops gained the most (478.699). This can be considered a reasonable result because of crop planting after first image was acquired.

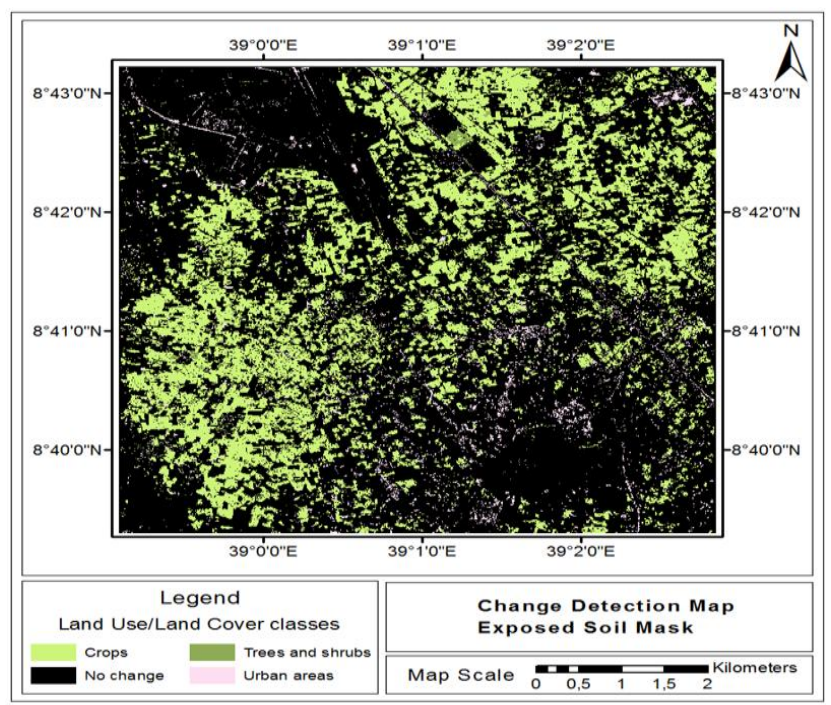

Fig. 7. Change detection final map, exposed soil mask.

\section{IDENTIFICATION OF BEST ALTERNATIVE TEF GROWING REGIONS}

The classification scheme for raster calculation used to generate tef suitability map is presented. Values presented here were based on literature review and expert's consultation to establish class limits for a modeling scenario where Raster calculation values used to generate tef suitability map and a chosen set of soils is deemed optimal for tef cultivation. 


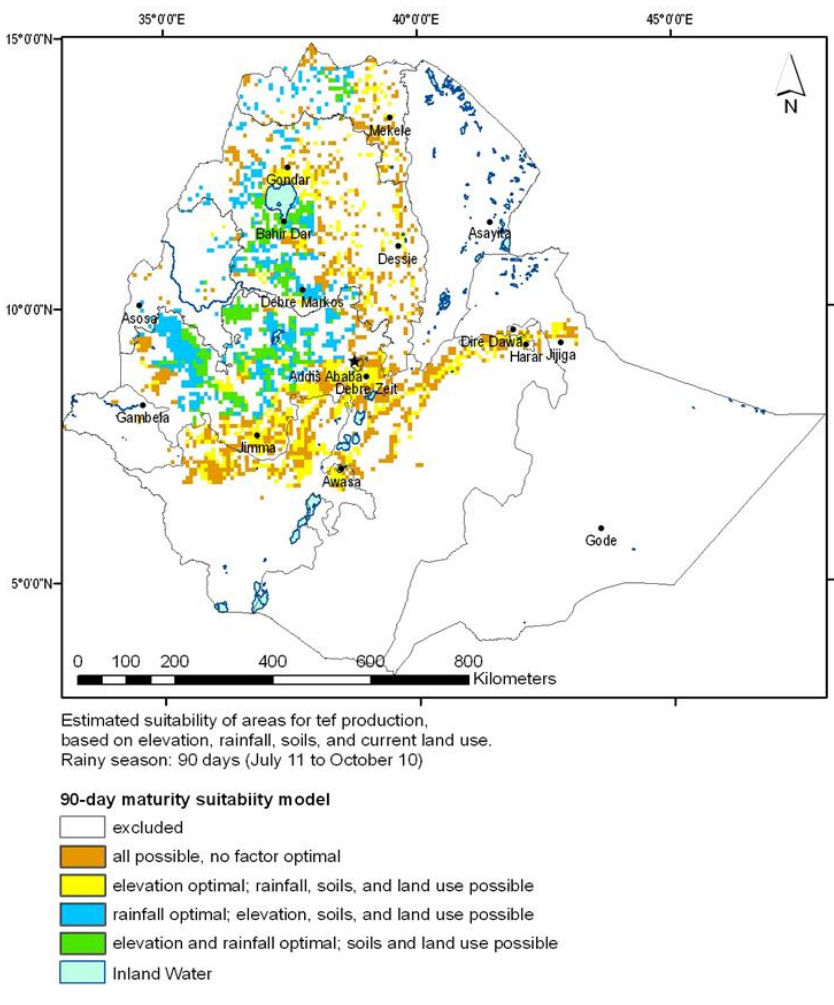

\section{CONCLUTION}

Regarding tef suitability analysis, information gathering made possible to achieve initial goals of producing a suitability areas map for tef cultivation. Adjustments could easily be made on the final map in case more detailed information is obtained or whether different class limits are found for suitable areas cultivation. Soil mapping at a local scale provided important information that can be used, for sampled area, to produce more detailed suitability maps not only for tef but for other crops as well.

This result focuses on identifying drought beginning, end, spatial extent, and severity of the drought in a given region and is based on scientific reasoning. Once the analysis is conducted it is beneficial in developing drought policies, early warning monitoring systems, mitigation strategies, sustainable production management/development and preparedness plans.

\section{ACKNOWLEDGMENT}

The authors are grateful and appreciative for the Federal Democratic Republic of Ethiopia agencies, Ada'a-debrezeit local farmers, George Mason University and all research centers pointed out above for unlimited support.

\section{REFERENCES}

[1] Bhan, S.K.; Saha, S.K.; Pande, L.M.; Prasad, J. Use of Remote Sensing and GIS Technology in Sustainable Agricultural Management and Development. Indian Institute of Remote Sensing, NRSA DEHRADUN-248001, India. 1996 pp.7-9.

[2] Central Statistical Authority (CSA), 2008: Statistical Abstract of Ethiopia 2008. Ethiopian agricultural research organization, Addis Ababa, Ethiopia.

[3] Earth Observation Portal https://directory.eoportal.org/web/eoportal/satellitemissions/g/geoeye-1

[4] Envi 5.0. Envi 5.0 User's Guide. Boulder, Colorado: Exelis Visual Information Solutions. 2011.

[5] ETHIOGIS. http://www.ethiogis.net/

[6] FEWS (Famine Early Warning System) http://earlywarning.usgs.gov/fews/africa/web /datatheme.php

[7] Show,T. 1976. Early crops in Africa: A review of the evidence. In. J.R. Harlan, J.M.J. Dewet and A.B.L Stemler (Eds.) Origins of African plant domestication, Moutn publishers, The Hague, Paris. PP.107-153.

[8] Tadesse Ebba. 1975. Tef (Eragrostifs tef) cultivates Rs. Morplogy and classification. Part II. Agricultural Experiment Station Bulletin, 66, Addis Ababa university, college of agriculture, Diredawa, Ethiopia

[9] Waterworks Design and Supervision Enterprise http://www.wwdse.com.et/

[10] "United States Geological Survey (USGS); (EROS) Earth Resources Observation and Science Center. http://eros.usgs.gov/\#/Find Data/Products and Data Available/gtopo30 info. 